\title{
A BROADER AND DEEPER IDEA OF FAIRY TALE: REASSESSING CONCEPT, MEANING, AND FUNCTION OF THE MOST DEBATED GENRE IN FOLK NARRATIVE RESEARCH
}

\author{
Vito Carrassi
}

\begin{abstract}
In this essay I try to argue a broader and deeper notion of fairy tale, beginning from an overview of some of the key terminologies and classifications devised and employed by folk-narrative research, passing through an etymological and semantic scrutiny of the word 'fairy', and developing, eventually, a structural analysis purposely framed within the historical-cultural context of the Irish tradition. What I attempt to let emerge - challenging to some extent the established concepts and theories - is a more comprehensive narrative category, characterised by a specific epistemological and ontological value, through which a sort of intermediate, neutral space is modelled, where boundaries are crossed and elements more or less heterogeneous are connected. Thus, the fairy tale can express a multi-dimensional worldview and the potential for a more complex idea of reality.
\end{abstract}

Keywords: belief, classification, etymology, fairies, fairy tale, Ireland, narrative genres, otherness, supernatural, worldview

\section{INTRODUCTION}

Let me begin with a basic question: what is a fairy tale? Or even better: what does fairy tale mean? What do we mean when we say "fairy tale"? Certainly, fairy tale is one of the several genres by which folk narrative tradition is classified. But what is a (narrative) genre? As Willem de Blécourt (2012: 9) puts it: "I consider a genre as a rather stable, encompassing category. Such a category may be used, albeit differently, by both narrators and theorists." According to Ülo Valk (2012: 23):

Genre is one of the fundamental concepts of folkloristics, reminding us that vernacular orality takes traditional forms. The idea of generic qualities of folklore helps us to create preliminary order in huge corpuses of recorded texts. [---] Genre is a gap that keeps some texts apart and a bond that ties others together. 
Hence, if the fairy tale is a genre, and a genre is an encompassing category as well as a gap keeping apart and a bond tying some texts, then the fairy tale could be considered as a sort of homogeneous and well-ordered space - within the greater space of folklore - including a certain kind of narratives sharing a certain number of qualities. Yet, the scope and the meaning of narrative genres is all but a clearly established issue - if anything, a subject of numerous and multifarious discussions and arguments. There are too many elements and variables to take into account to reach a final and absolute agreement. In Stith Thompson's words (1977 [1946]: 7): "Much hair-splitting has taken place in the past and much useless effort devoted to the establishment of exact terms for the various kinds of folktale." However, in the following line, he clarified: "Yet some very general terms are not only helpful but necessary" (ibid., my emphasis). Classifying is a complex and potentially counter-productive work; nonetheless, we cannot do without it, at least in a very general way. ${ }^{2}$ Accordingly, my proposal is that the genre of fairy tale, rather than a whatever - and quite limited - narrative item among many others might be interpreted, through a structural and historical-cultural reassessment, as an epistemological tool by which individuals and communities can explore the world around them. At the same time, it might function as a sort of ontological category, flexible enough to provide a very general classification of the folk-narrative tradition and a deeper view on reality itself.

To be sure, the concept of fairy tale is one of the most controversial issues in folklore research, ${ }^{3}$ the main problems deriving from the meaning(s) associated with the term 'fairy' (and 'fairies'). Let us read, for instance, the opening lines of an essay about fairy tale by Ruth Bottigheimer (2003: 57): "The term 'fairy tales' connotes tales about fairies such as 'The Yellow Dwarf' as well as fairy tales like 'Cinderella' and 'Puss-in-Boots'. Tales about fairies and fairy tales differ considerably from one another." She draws a clear-cut distinction between these two genres:

Tales about fairies treat fairyland and its fairy inhabitants [---] as well as the complex relationships that develop between fairies and human beings. [---] Fairy tales are commonly narratively and lexically simple, may or may not include fairies, unfold along predictable lines, with magically gifted characters attaining their goals with thrice-repeated magical motifs. (ibid.)

This (alleged) ambivalence entails that many "folk-narrative scholars prefer the analytic term 'magic tale' or 'wonder tale' to the more popular 'fairy tale' because fairies rarely appear in such tales" (The Greenwood Encyclopedia 2008: 214). ${ }^{4}$ On the contrary, I think that the concept of 'fairy tale', more than those of 
'wonder' or 'magic' tale, has a clear analytic value by which one can encompass both tales about fairies and fairy tales - along with other kinds of narratives. We need to assume an idea of 'fairy' not just as a mere synonym for 'wonder' or 'magic', but in light of a broader and deeper meaning, allowing to go beyond the traditional dichotomy between wonder/magic and belief, and to build a bridge between the canonical notions of the fairy tale (or Märchen) and legend (or Sage). To the question posed by de Blécourt (2012: 10) - "Are there any narratives without some sort of 'belief'?" - I would answer negatively: in fact, one may not conceive the ideas of magic, wonder, and, above all, fairy separated from "some sort of belief", all the more in the living historical and cultural context of storytellers, their listeners, and the larger folk-society ${ }^{5}$ - unlike what happens when folk-narratives are removed from their original contexts and re-framed in a literary sphere, where they become self-referential and purely aesthetic items. ${ }^{6}$ This is, for instance, the case with the French conte de fées, from which the English term 'fairy tale' derives, as well as the usual meaning ascribed to it. ${ }^{7}$ Likewise, may we say that legends or belief narratives in general are lacking in magic or wonder? Indeed, they are often the foremost elements of these stories, even the very motive of their passing on; and I am not solely referring to the abovementioned tales about fairies. Thus, I believe it could be useful to find a different and more objective criterion leading to a very general classification in the mare magnum of folk-narratives.

In my opinion, starting from an overview of some classical definitions and classifications in the folk-narrative studies, paying critical attention to the place and role reserved to the fairy tale, passing through an etymological and historical re-evaluation of the word 'fairy', and framing it in a suitable culturalhistorical context - as I believe the Irish one is - it is possible to address the vexata quaestio of the fairy tale from a quite innovative and thought-provoking (at least I hope) point of view. I am dealing with a dynamic and changing field of research, affording several and varying opinions, approaches, and interpretations, as demonstrated by the history of our studies, especially by its latest developments. ${ }^{8}$ Nevertheless, it is exactly this long and strengthened history that has sewn a sort of sacred veil around the more or less traditional idea of 'fairy tale', within the greater system of folk-narrative genres. I will try to ignore this veil, at my own risk, so as to supply a useful contribution to redefine the function and the sense of a thing named 'fairy tale'. 


\section{A THEORETICAL OVERVIEW}

My analysis begins with the seminal and theoretically all-embracing classification provided by Aarne-Thompson's The Types of the Folktale (AT 1961) - later revised and enlarged by Hans Jörg Uther (ATU 2004). In this catalogue, the narrative material is organised according to numerical succession, from 1 to 2399; each number corresponds to a specific type, i.e. a narrative pattern in which all the stories roughly conforming to a same plot can be included. More generally, the types of the ATU Index are grouped and subdivided in seven broader categories, basically identifiable as different narrative genres: Animal Tales, Tales of Magic, Religious Tales, Realistic Tales, Tales of the Stupid Ogre, Anecdotes and Jokes, Formula Tales. Each of them, in its way, is split in several sub-categories, each comprehending all the tales sharing a specific character, a certain class of characters, or any other distinguishing feature. Famously, the fairy tale falls under the second category, Tales of Magic (numbers 300-749), whose all sub-categories, except one, refer to the concept of supernatural, which is clearly regarded as the major and noteworthy trait of these narratives.

To be sure, supernatural cannot be considered as an exclusive feature of Tales of Magic; its key function in most Animal Tales or Religious Tales, for instance, is unquestionable. And yet, according to this typological classification - regardless of its insufficiencies and drawbacks (Propp 2003 [1958]: 10-11) - only in the so-called Tales of Magic (i.e. fairy tales) the supernatural has such a prominence and significance to deserve explicit recognition. Consequently, to tell a fairy tale would mean to tell a story concerning figures, phenomena, situations, and beliefs included in that indefinite, mysterious, fascinating, dreadful subject called supernatural, which gathers all that lies beyond the natural, known, usual, realistic boundaries of the daily life: a sort of parallel and alternative world with its own rules and customs, more or less different from those being current in our world. In other words, the fairy tale, through the extraordinary experiences or adventures of a hero, or the vivid imagination of a storyteller, would disclose a more or less hidden dimension of reality, bringing to the fore such concepts as magic and wonder, as well as marvellous, fabulous, preternatural, fantastic, miraculous, numinous, uncanny, and so on: all concepts that, in different ways, are used both by scholars and storytellers to try to explain the distinctive otherness of this genre and its topics. Ultimately, the fairy tale could be seen as the narrative place in which a radical otherness, recognised as such - and otherwise unknown or scarcely known - takes a visible, identifiable, and shareable form: "An other world is very much alive in fairy tales, thanks to our capacity as storytellers," an other world where it is possible to "create and re-create gods, divine powers, fairies, demons, fates, monsters, witches, and other supernatural characters and forces" (Zipes 2012: 4). 
Moreover, the notions of supernatural and otherness appear to play an essential and paradigmatic role in the morphological analysis proposed by Vladimir Propp (2003). In order to surmount the insufficiencies and drawbacks bound up with the typological classification, Propp brings back all the fairy tales to a single and universal pattern of 31 character functions. According to this outline, among other things, there would not be a (fairy tale) plot without a villainy committed by a villain, or a lack felt by a character (the main function 8 ). Though, it is also indisputable that, without the departure of the hero destined to restore or improve the initial situation (function 11), the plot would not start at all and, consequently, there would not be any journey or adventure in another world where the hero might accomplish her/his tests and deeds. As such, the fairy tale hero must leave, though temporarily, her/his home, cross the threshold between the known and the unknown, and advance into another dimension of reality, where he/she chiefly encounters supernatural beings and phenomena. Note that the key figures of donor (functions 12-14) and villain (functions 16-18) are usually supernatural characters, who help or contrast the accomplishment of a heroic task; the task that entails not only the defeating of the villain and a triumphant comeback home, but also the discovery or a clearer knowledge of the world beyond our world. Indeed, another world.

However, is all that we identify as supernatural present in the domain of the fairy tale? If so, it would be an exceptionally widespread and certainly very general narrative category, theoretically able to encompass all the genres somehow relating to the vast concept of supernatural, leaving aside just the genres involving natural subjects. In fact, looking at the main scholarly definitions and classifications in the field of folk narratives, it clearly appears that the supernatural items are not regarded in the same way, but are essentially distinguished according to their level of belief or believability, namely whether and how they are believed as true, trustworthy, even historical, or, instead, as false, fanciful, and merely fictitious.

A dichotomous theorisation is already present in the Grimm Brothers, with their well-known distinction between Sage (legend) and Märchen (fairy tale) based on a "believing determinant" (Jason 1971: 143). According to this one, "the legend is a true story" dealing "with supernatural events [---] 'believed' by its bearers" and "regarded as pertaining to the real world of the narrator and his audience," whereas "the fairy tale, to the contrary, is not believed by the narrating community, although it too deals with supernatural events" (ibid.: 134). Both these very general genres, therefore, deal with the same theme, "supernatural events," but they differ because one of them is believed to be true, or at least believable, while the other is not, in a sort of opposition between the (real) 'history' and the (poetical) 'fiction'. ${ }^{9}$ 
This opposition characterises, to a variable extent, all the subsequent terminologies and classifications. Interestingly, Edwin S. Hartland, in Popular Studies in Mythology, Romance, and Folklore (1914), builds his taxonomy on an ambivalent interpretation of the concept of 'fairy': on the one hand there are the "fairy tales," or Märchen, on the other hand the "tales about fairies", or Sagas, the former intended as tales of marvellous events not to be believed seriously, the latter as serious tales more or less linked to historical places and characters. Conversely, the ambivalence inherent in the concept of 'fairy tale' - "Fairy tale seems to imply the presence of fairies; but the great majority of such tales have no fairies" (Thompson 1977 [1946]: 8) - leads Stith Thompson to prefer the German Märchen, which he describes as "a tale of some length involving a succession of motifs and episodes. It moves in an unreal world without definite locality or definite characters and is filled with the marvelous" (ibid.). On the opposite side there is the Sage, defined as a tale purported "to be an account of an extraordinary happening believed to have actually occurred. [---] It may tell of an encounter with marvelous creatures which the folk still believe in" (ibid.). Incidentally, it is noteworthy that both these genres, though in a different way, share a common subject: the marvellous, or supernatural. Thompson enumerates several other genres, yet the antithetical pair formed by Märchen and Sage appears to play, also by virtue of a scientific and historical relevance, a key role in the classification of the folk-narrative material (see also Lüthi 1986 [1982]), which is thus ordered according to a more extensive criterion, certainly more practical than those based on formal or content features - as for the typological ATU Index. But, I would say, not more objective, if only we think of the obvious and intrinsic variability and instability of such concepts as belief, believability, or truthfulness, which are affected by a number of changing contextual factors, without overlooking the 'individual' factor, as highlighted by Heda Jason (1971: 143): "Today we know that the quality of any narrator's attitude towards his tale is unstable, that it varies from individual to individual and even from period to period in the lifetime of a single individual." Likewise, as Willem de Blécourt points out (2012: 9): "[---] the concept of 'belief' is unsuitable for academic purposes, indeed it is often hard to determine whether an informant 'believes' in something or not, or is unsure about it, or changes his/ her mind in different situations."

As a rule, the main scholarly classifications opt for a tripartition of folk narrative material, sometimes applying in a more gradual way the classical believing-centred principle. William Bascom (1965: 3) espouses the term "prose narratives" to designate all forms of "verbal art which includes myths, legends, and folktales." These three general categories are identified according to a combined evaluation of time and truth factors: 
Folktales are prose narratives which are regarded as fiction. [---] Myths are prose narratives which, in the society in which they are told, are considered to be truthful accounts of what happened in the remote past. [---] Legends are prose narratives which, like myths, are regarded as true by the narrator and his audience, but they are set in a period considered less remote, when the world was much as it is today. (ibid.: 4)

The use of the term 'folktale' instead of 'fairy tale' - a use that has become customary in the scholarship, above all in order to distinguish between the oral/popular folktale and the written/literary fairy tale ${ }^{10}$ - is explained again: "because narratives about fairies are usually regarded as true, and because fairies do not appear in most folktales" (ibid.). In other words, fairies, as "usual" matter of belief, should not be connected to narratives regarded as pure fiction. However, as already said, I am really doubtful about the existence, in the field of folklore, of absolutely fictitious narratives. On the other hand, if the fairies, according to Bascom (and many others), are "usually" believed as true, when and why are they believed as untrue? Ultimately, is a clear distinction between the concepts of 'fairy' and 'fairies' quite necessary? I will return to this issue later on.

According to Linda Dégh (1972: 59-60), "As long as they [folk narratives] are told, they vary, merge, and blend; a change in their social value often results in a switch into another genre." After this cautionary statement, she proposes, "for practical purposes," to "divide the narrative genres into tale genres, legend genres, and true experience genres" (ibid.: 60). More than genres, these appear as wider categories, each including those genres sharing a similar degree of believability and truthfulness. Interestingly, beside tale (i.e. fairy tale, even though Dégh prefers Märchen) genres and legend genres, "true experience genres" are also present, so making more gradual the transition from fairy tale to legend. Furthermore, referring to the AT Index, she maintains that "the Märchen themes center on man's fascination with the supernatural adventures. They tell about an ordinary human being's encounter with the suprahuman world and his becoming endowed with qualities that enable him to perform supernatural acts" (ibid.: 62-63). Again, the supernatural is the key concept. It is seen as a fascinating matter related to a world beyond the ordinary world, another world discovered through the journey of an ordinary human being coming from the 'real' world of narrator and her/his listeners - able to cross the threshold dividing two or more dimensions of reality.

The tripartition suggested by Steven Swann Jones retains the canonical terms, but these are intended from a pretty different perspective:

Myths are etiological narratives that use gods (divine, immortal figures) to explain the operation and purpose of the cosmos. Legends are quasi- 
historical narratives that use exceptional and extraordinary protagonists and depict remarkable phenomena to illustrate cultural ideals, values, and norms. Finally, folktales are entertaining narratives that use common, ordinary people as protagonists to reveal the desires and foibles of human nature. (Swann Jones 1995: 8)

Here, the key distinction deals with the nature of the protagonists and of their contexts, according to a range including mythical gods (non-humans), legendary heroes (extraordinary humans), and common people (ordinary humans). Rather than focusing on an exterior issue, as the attitude of people towards the narratives, this classification seems to emphasise internal factors as their characters and space-time coordinates. In this arrangement, fairy tale is interpreted just as a sub-genre of folktale, but it is characterised by a momentous and distinguishing feature: "While these other genres of the folktale are reasonably mimetic - that is, they depict life in fairly realistic terms - fairy tales depict magical or marvelous events or phenomena as a valid part of human experience" (ibid.: 9). Thus, the peculiarity of fairy tale lies in its representation of events and phenomena reminding us of the abovementioned notion of supernatural, whose radical otherness is interpreted as a significant and serious experience, "not to be taken lightly, but rather to be regarded with respect and even some trepidation" (ibid.: 10): a claim that would seem fitting for a sacred myth or a quasi-historical legend rather than for pure fiction as a fairy tale should be.

\section{AN ETYMOLOGICAL SCRUTINY}

Perhaps, if we look at the true subjects of folk narratives - in our case, the supernatural, in all its variety, and the radical otherness revealed through it - from a structural point of view, we could find the way to gather them in a more comprehensive and very general category. This way, in my opinion, deals with the potential implied in the pair formed by 'fairy' and 'tale' - as suggested, indeed, by some of the abovementioned authors - first and foremost with an etymological reassessment of the word 'fairy', so as to retrieve all its semantic scope and historical-cultural meaning.

For this purpose, I turn to the scrupulous and detailed analysis provided by Noel Williams in his essay, "The Semantics of the Word Fairy." Despite the difficulties by and large concerning the etymology of words referring to the supernatural (Williams 1991: 460-462), he is able to assert a generally accepted history of the term 'fairy', "derived from words denoting female supernatural creatures in other languages." More precisely: 
[---] it would seem to be derived from Latin fatum = 'thing said.' This gave fata = 'fate,' a neuter plural which, it is supposed, was misinterpreted in the Dark Ages as feminine singular, fata = 'female fate, goddess,' and these goddesses of fate were supposedly identified with Greek Lachesis, Atropos and Clotho. (ibid.: 462)

At this early stage, the notion of fairy, or better fata, seems to suggest a sacred and numinous idea of femininity, an idea dealing with the mysteries about the human destiny and the otherworldly. Interestingly, this meaning of Latin fata, following the Roman conquest of Celtic countries, appears to be associated with "various Celtic female deities" (ibid.), giving rise to a lasting and substantial connection with the Celtic culture (ibid.: 462-463, 468-470).

Leaving aside all the "imperfections and difficulties" (ibid.: 463) relating to an accurate etymological survey of the word 'fairy', I believe it is crucial, for our discussion, to emphasise the semantic expansion it had during its historical evolution:

All agree that fata was interpreted as feminine and eventually gave four distinct meanings in Old French which passed into English, namely (1) enchantment, illusion; (2) fairyland, land of illusion; (3) human with special power; (4) supernatural beings. (ibid.: 463)

Therefore, beside supernatural beings, 'fairy' identified: a class of humans whose powers connected them to the supernatural; a kind of phenomena linked to a supernatural interference producing an alternative, illusory perception of the reality; a magical, fantastic place in which supernatural beings were believed to dwell. In consideration of this fourfold meaning, one is allowed to include, in the concept of fairy, fundamentally all those figures, phenomena, and events challenging the ordinary and officially accepted idea of reality, and showing the existence of other dimensions, parallel worlds, alternative realities. In this light, Swann Jones may properly claim, referring to Joseph Campbell, that in the fairy tale the fantastic and the quotidian "are perceived as coexisting in tangential worlds that the protagonist experiences and must reconcile" (Swann Jones 1995: 15). As we are going to see, this is a very fruitful view if placed in the context of the Irish tradition.

However, through its historical and literary investigation, Williams arrives to distinguish between fay, more directly related to the Latin fata, and fairy itself, coming to an important conclusion: "[---] the notion of fairy in its earliest uses is not primarily to denote creatures, but a quality of phenomena or events which may or may not be associated with creatures" (Williams 1991: 464). Hence, originally, rather than designating a supernatural female creature - whence it 
passed to denote figures, places, and phenomena more or less correlated - the word 'fairy' would have had a more general and comprehensive meaning, an adjectival sense concerning a quality characterising not only creatures but also phenomena and events, thus identifying a veritable otherworld, alternative to the daily one. This quality referred to a very significant semantic field, quite different from the one we are used to assign to the 'fairy', as Williams explains:

Such a concept may lie in the vague idea of "fatedness," a quality in the world which can control and direct the actions of humanity, and hence is more powerful than humanity. For example, there is clearly a link between the idea of fate and that of death. Death is perhaps the mystery for which people feel they can never have an explanation fully adequate to their experience and the supernatural, in its widest sense, has always been connected with death, and is probably universally so. (ibid.: 465)

This connection between the 'fairy' and the supreme mystery of death ${ }^{11}$ - alongside the other incomprehensible facts relating to the human existence and the afterlife - gives us the most significant clue to grasp the full extent of a concept that, over the centuries, was ontologically and epistemologically shrunk, at least in the fields of literature and learned culture, where it underwent a progressive assimilation to the only dimension of 'fairies' (fées), namely to those supernatural beings par excellence representative of a magical, enchanted, illusory otherness, framed in a purely fictional and escapist kind of narratives. The semantic affinity between 'fairy' and 'fatedness' compels to reconsider, from a broader and deeper point of view, the role and meaning carried out by the whole world of fairies - and not merely by single figures known as fairies - in the folk narrative tradition, where the original sense of the term 'fairy' identified by Williams appears to survive and retain a real significance.

\section{THE IRISH FAIRY TRADITION}

I think that the Irish context is particularly suitable for an evaluation of the actual breadth and depth of the concept of 'fairy'. As an essential element of folklore, this concept lies at the core of a complex system of beliefs and worldviews labelled as fairy faith or fairy lore, which, even though "is known from many countries [---] only in some places has it remained an active element in the life of the people. One such place is Ireland" (Christiansen 1971-1973: 101). If intended as "the complex of beliefs connected with the existence of another race side by side with man but normally invisible to him" (ibid.: 95), fairy lore is certainly just a part (the major part, as it seems) of a wider historical-cultural 
system based on the multifaceted concept of supernatural, more specifically, a pretty organic set of beliefs that "has been an integral part of the world view of the Irish people over many centuries" (Lysaght 1995: 289). However, if we restore its early adjectival meaning, the notion of fairy would be allowed to include the several yet also similar meanings related to the concept of supernatural, which can be summed up as 'fatedeness', as explained by Williams. On the other hand, the nature of fairies as beings and fairyland as a place existing side by side with the humans and their world epitomises those historical and cultural events which, to a great extent, have shaped, as it were, the whole supernatural topography and brought about its influence on the earthly events. It is exactly in this spatial closeness, inherent connection, and functional correlation between worlds that one could identify the epistemological and ontological peculiarity of a redefined idea of the genre of fairy tale. An idea implying the multidimensionality of reality and the possibility - no matter how much believable or believed - of passing from one dimension to another; a means, therefore, to conceive and try to understand the radical otherness of all those things, beings, and phenomena alien to the common experience, yet deep-seated in folk mind and imagination (and elsewhere). To this end, I find extremely suggestive the following excerpt from Thomas W. Rolleston:

But the People of Dana do not withdraw. By their magic art they cast over themselves a veil of invisibility, which they can put on or off as they choose. There are two Irelands henceforward, the spiritual and the earthly. [---] Where the human eye can see but green mounds and ramparts, the relics of ruined fortresses or sepulchres, there rise the fairy palaces of the defeated divinities [---]. The ancient mythical literature conceives them as heroic and splendid in strength and beauty. In later times, and as Christian influences grew stronger, they dwindle into fairies, the People of the Side; but they have never wholly perished; to this day the Land of Youth and its inhabitants live in the imagination of the Irish peasant. (Rolleston 1911: 136-137)

To me, in these few lines, Rolleston supplies a suggestive and quite significant picture, evoking a much longer and more tangled history, let us say the more or less fictionalised history of Ireland and its invaders (described in an exemplary way in a medieval Irish collection of narratives known as Lebor Gabála Érenn, or The Book of Invasions, and brilliantly reprised and summarised by such a writer as James Stephens in his "The Story of Tuan Mac Cairill," included within a narrative anthology intriguingly titled Irish Fairy Tales). This history begins from the epical defeat suffered by the mythical Túatha Dé Danann against the legendary people, Milesians, and arrives to the author's 
present. Rolleston outlines not only the synchronic landscape and the main characters of thousands of stories belonging to the Irish narrative tradition, but also their origins and the diachronic progression and change of a broader historical context. As is well known, this context can be summed up into a fourcycle classification, through which scholars have roughly sorted and catalogued the massive and heterogeneous material of Irish narrative tradition according to a chronological and more widely cultural principle (for a brief but complete overview see Ní Bhrolcháin 2009: 26-77). Therefore, we have a 1) Mythological Cycle, a 2) Heroic or Ulster Cycle, a 3) Fenian Cycle, and a 4) Cycle of the Kings or Historical Cycle. Overall, these cycles sketch a historical sequence applicable out of Ireland too (I am referring, in particular, to G. B. Vico and his seminal idea of the Three Ages of humankind) - in which a mythical age (1), a legendary age (2 and 3), and a historical age (4) follow one another. Each of these cycles, with its own stories, reflects frameworks, worldviews, systems of beliefs and values, so as one might find in them traces, signs, and figures referring to the past, or better, to the pasts that have followed and overlapped, as suggested by Rolleston, one another up to the present. It is exactly in this overlapping, spatial - "there are two Irelands [---] the spiritual and the earthly," in Rolleston's words - and temporal - because the past, instead of disappearing, coexists, in the form of fairies and sacred places, with the present - that the domain of fairy tale can be identified. Consequently, the fairy tale is conceivable as a sort of intermediate or neutral space - real or figurative - whose boundaries act as a wide frontier of transition that makes possible the encounter between the several and varied elements scattered by the ages, contexts, peoples, and societies that, along with their mythological, ideological, philosophical, ethical, and religious paradigms, have given rise to the complex and layered cultural identity of Ireland. Perhaps, a graphic outline could be useful to make clearer my subject (see also Mincu 1978).

Otherness

(Angels, Demons, Saints)

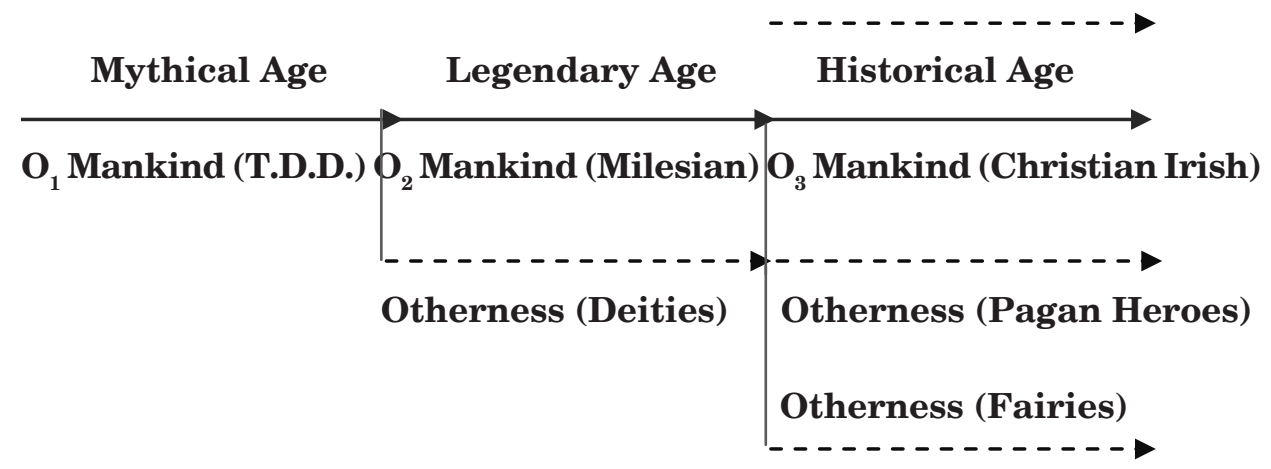


By this figure I try to provide a diachronic and synchronic representation of the events evoked by Rolleston and, more generally, a sketch of the historical and cultural configuration that characterises the Irish fairy tales. The three capital Os denote as many 'origins', namely three turning points, in the Irish history and its narrative tradition, entailing a paradigmatic change that caused a new spatial landscape and an ontological evolution in some individuals and peoples. Here one can identify the origins of various forms of otherness, more or less connoted as supernatural: $\mathrm{O}_{1}$ labels the arrival in Ireland of the Túatha Dé Danann, seen as the earliest (though forerun by other peoples that later disappeared) settlers of the country and the founders of its history; $\mathrm{O}_{2}$ labels the aforementioned victory of the Milesians - regarded as the ancestor of modern Irish people - over the Danann, who are compelled to pass into another, parallel and invisible, dimension, and now viewed as deities; $\mathrm{O}_{3}$, finally, labels the coming of Saint Patrick and the subsequent conversion of Ireland to Christianity, which produces the transition of Milesians into a heroic-pagan dimension, the transformation of Danann into fairies, and the triumph of the Christian God along with his related transcendent figures. What we see, therefore, is an increasing set of parallel lines referring to a series of parallel worlds that, far from disappearing, survive (though modified) and set off a dialectic - especially by means of narratives - with the objective and visible world, i.e. the human world. This functions as a paradigm of reference, as the norm opposed to the anomalies which, on certain occasions, come out, in the form of beings or phenomena, from coexisting dimensions of reality that had been, in their turn, the paradigm of reference, that is, before the advent of a new historical-cultural age and of a new species of mankind. What pertains to the past(s) falls into the sphere of subjective and invisible, in a more or less indistinct and ambivalent otherness that yields an increasingly large stock of stories set in the liminal spaces and moments where what exists encounters what existed and/or could still exist. This process is more relevant in Ireland than elsewhere: differently from the rest of Europe, the advent of Christianity and its progressive achievement did not mean the disappearance or the repudiation of the pre-existing pagan-Celtic heritage, but brought about a syncretistic - then stratified and more complex - culture, especially regarding the fairy lore and fairies (see Ó Giolláin 1991: 199-203).

To recognise the co-existence of parallel dimensions leads to a broader and deeper view on reality and life itself, furthering the exploration of unknown or less known horizons, as fragile, fading, and indefinite they may turn out to be. It is precisely such indefiniteness that makes this plurality of alternative dimensions more significant: if, on the one hand, it causes uncertainties, doubts, fears, not to say a perpetual disorientation, then, on the other hand, it debunks 
stereotypes and assumptions of any kind and generates a constant and fruitful questioning of the world we live in, giving rise, to use the Bakhtinian terms, to a dialogic, carnivalesque worldview.

Operating as a sort of bridge linking several dimensions of reality, as a threshold connecting parallel worlds, the fairy tale, in order to make a potential space to contact an actual place of encounter, needs the pragmatic action by individuals or groups of individuals - the hero, according to Kurt Ranke, "is a traveler between the worlds" (quoted in Dégh 1972: 63) - who, crossing their boundaries, leave their own world and undergo the possibility of interacting with someone or something pertaining to an "unbounded" outside (Ó Giolláin 1991: 201). Just as, for instance, Jamie Freel does, willingly going to "an old ruined castle" that "was said to be the abode of the "wee folk" (Jamie Freel and the Young Lady, Yeats 2002 [1888]: 54), or Jack Dogherty, who boldly dives down to "the bottom of the sea" to know the house of a merrow (The Soul Cages, ibid.: 71). The domain and the boundaries of the fairy tale genre are thus unstable and changeable; they depend on the changes in knowledge, beliefs, fantasies, fears, practices, and concern about the supernatural, as well as on the historically and culturally varying conceptions about what should be regarded as radically 'other' in respect to themselves. In other words, a fairy tale can theoretically occur anywhere, provided that there are the right actors and the favourable circumstances. ${ }^{12}$ Of course, the right actors can also be the 'others', whenever they happen to leave the otherworld and come into ours. Think, for instance, of the "little weeshy woman, dressed in a neat red cloak" coming into Paddy Corcoran's house to visit his sick wife (Paddy Corcoran's Wife, ibid.: 33), or the púca who "came behind" a piper and "flung him on his own back" (The Piper and the Púca, ibid.: 102). Obviously, this is only true as long as there are women and men willing and/or able to see these 'others', to accept and recognise their existence, or, at least, to tell stories about them.

\section{CONCLUSION}

To come to an end, I would refer to an old but stirring article by C. Scott Littleton, "A Two-Dimensional Scheme for the Classification of Narratives," whose proposal of a more general and functional classification of narratives has something in common with my attempt to broaden the scope and deepen the meaning of the fairy tale. To be sure, Littleton does not propose a new idea of the genre, but provides a scheme arranging all the traditional genres according to the two criteria he believes to be more important than any other, namely "the relative degree to which a narrative is grounded in fact or fancy," and "the relative 
sacredness or secularity of a narrative" (Littleton 1965: 21). These criteria are translated into dichotomies, "two polarities or ideal types," "between absolutely factual (or scientific) and absolutely fabulous (or non-scientific)," and "between absolutely secular and absolutely sacred" (ibid.: 21-22). As Littleton himself admits, indeed, "it is, of course, difficult to quantify the degree of sacredness or secularity of a narrative, let alone the degree to which it is factual or fabulous" (ibid.: 22). In my opinion, to classify the narratives according to their higher or lower degree in a specific quality can be a useful means to avoid the stiff discontinuity generated by the traditional genres, and can give a more flexible view of the boundaries between different narratives. Nevertheless, I find the criteria chosen by Littleton certainly pertinent and significant, but also quite fluid, relative, too much subject to individual attitudes and contextual factors, such as the already discussed criterion of belief/believability. I propose, instead, a structural dichotomy based on the pair fairy tale / tale, where the difference would lie in a more or less stratified and multidimensional worldview, in a higher or lower presence of the supernatural, in a more or less radical otherness of characters and phenomena involved. Thus, the fairy tale would become the narrative pole of the ontological complexity and of the epistemological challenge, finally a very general category encompassing all those narratives - be they myths, legends, folktales, wonder tales, sagas, and so on - showing a reality whose several levels are connected by the overtaking of their boundaries.

\section{NOTES}

1 Intriguingly, fifty years later Linda Dégh (1996: 42) wrote: “The hairsplitting exercise of discriminating between categories and subcategories, assigning names, and determining 'analytical categories' began early and is still going on, as if modern authors would be persuaded to invent new terms for their new collections in line with the fashionable trends of other disciplines. New terms are also a risky business because they often turn out to be the reinvention of the wheel."

${ }^{2}$ Cf. Bascom (1965: 3): "Definitions and classifications are neither particularly interesting nor necessarily fruitful, but if any field of study needs clarification of its basic terminology it is clearly folklore, which has so long been plagued by inconsistent and contradictory definitions."

3 See, for instance, the entry "Fairy Tale" in The Greenwood Encyclopedia of Folktales and Fairy Tales (2008: 322): "Despite its currency and apparent simplicity, the term 'fairy tale' resists a universally accepted or universally satisfying definition. For some, the term denotes a specific narrative form with easily identified characteristics, but for others it suggests not a singular genre but an umbrella category under which a variety of other forms may be grouped." Indeed, I also argue an idea of fairy tale as a sort of 'umbrella category', as I try to prove in this essay. 
4 Cf., e.g., the use of "magic tale" by Linda Dégh (1972: 58) to translate the German Märchen and make clear the distinction between this and legend/Sage: "Since the historic statement of Jacob Grimm, 'das Märchen ist poetischer, das Sage historischer' (Deutsche Sagen 1816), folklorists have accepted the distinction between the magic tale (Märchen) and the legend. The two forms correspond to primary attitudes in human culture and by their very nature merge and blend into each other; the magic tale expresses the escape from reality, and the legend faces the facts of reality." Jack Zipes (2000: xvi), instead, adopts the term 'wonder tale', in which he includes the subgenre fairy tale: "The fairy tale is only one type of literary appropriation of a particular oral storytelling tradition related to the oral wonder tale, often called the Zaubermärchen or the conte merveilleux, which existed throughout Europe in many different forms during the medieval period."

5 It would be fitting, perhaps, quoting Linda Dégh (1996: 40-41), to reconsider "the time when practising fieldworkers and comparative text philologists realised that both genres [legend and Märchen] are based on a common belief system, a common monotheistic cultural knowledge, as is convincingly documented by Stith Thompson's Motif Index. The motifs, the smallest components of traditional narratives [---] can be regarded also as statements of belief, expression of worldview, charged attitudes and oppositions between fantasy and reality, the knowable and unknowable, life and death. It was no absurdity when legend scholars proposed to apply the Motif Index numbers for legend classification."

6 Cf. Zipes (2000: xvi): "During its long evolution, the literary fairy tale distinguished itself as genre by 'appropriating' many motifs, signs, and drawings from folklore, embellishing them and combining them with elements from other literary genres, for it became gradually necessary in the modern world to adapt a certain kind of oral storytelling called the wonder tale to standards of literacy and make it acceptable for diffusion in the public sphere."

7 About this topic, a passage from Susan Stewart's brilliant analysis of "distressed genres" (and fairy tale is one of these) seems very interesting to me, for it suggests the pre-existence - and the co-existence - of an oral narrative tradition that would allow to recognise a richer and deeper meaning in the term 'fairy tale' before it were absorbed into literature: "[---] considering that there was certainly a tradition of fairy lore within the European oral tradition, the term fairy tale is a rather recent literary invention. It dates to the 1698 publication of Madame d'Aulnoy's Contes de fées [---] In 1699, d'Aulnoy's book was translated into English as Tales of the Fairys. What should draw our attention to this French context is its transformation of an ambivalent and vigorous popular tradition into a literary form inseparable from the world of the antique, the child, the pastoral, the moral, and the fantastic" (Stewart 1991: 19).

8 The last decade, as a matter of fact, is characterised by a vibrant debate, particularly about the long-standing issue regarding the oral or literary origin of the fairy tale. For instance, the heated dispute raised by the controversial thesis expressed by Ruth Bottigheimer $(2002,2009)$ is quite significant. Her advocating an exclusively literary and relatively recent origin (16th century) of the fairy tale as a genre has entailed a number of vivid replies, above all, those of such eminent scholars as Jan Ziolkowski (2010), Francisco Vaz da Silva (2010), Dan Ben-Amos (2010) and, in a more biting way, Jack Zipes (2010). For an interesting and pondered point of view on the latest 
developments in this debate cf. the "Introduction" to Folktales and Fairy Tales (2016: xlvi): "That the oral and the literary need not exist in an oppositional relationship or be the defining terms of fairy-tale studies should be self-evident, especially in the twenty-first century. Folktales and fairy tales have manifested themselves in extraordinarily diverse ways, not just in oral and literary narratives [---]. This diversity of media and genres and the deficiencies in viewing texts as simply oral or literary have been underlined by major scholarship published since 2012 [---]. To be freed from our fixation on the oral-literary dichotomy and to make sense of the latest fairy-tale vogue that has accompanied globalization and the digital age, it is necessary not only to acknowledge the flexibility and adaptability of folktales and fairy tales but also to understand their dynamic intertextuality and intermedial potential [---]. It is also necessary to understand fairy-tale studies as an interdisciplinary effort."

9 Cf. Jacob Grimm's "Preface" to the second edition of Deutsche Mythologie, quoted in Dégh (1972: 72): "The fairy tale flies, the legend walks, knocks at your door; the one can draw freely out of the fullness of poetry, the other has almost the authority of history."

${ }^{10}$ Indeed, the dicothomy folktale / fairy tale appears to be an ideological and/or critical construction more than a thing really existing in the field; cf. The Greenwood Encyclopedia of Folktales and Fairy Tales (2008: 363-365): "[---] the folktale was conceived of as oral, whereas - although fairy-tale themes exist in folktales - the 'true' fairy tale was a literary genre [---] the cleavage between the fairy tale and the folktale, seen as the opposition between literary and oral forms, is an artificial aftereffect of the ideological trappings of the Romantic nationalists, a cleavage that is fundamental to the disciplinary niche of folklorists."

${ }^{11}$ Cf. Honti (1936: 39): "A thorough knowledge of Celtic religion of death is at any rate indispensable for the students of folk-tales. Tales are well-known to be the form of literature least marked by the notion of death, and nevertheless their connection with the always present idea of death is undeniable. It is Celtic religion and its attitude towards death which effaces the contrast between the concepts 'death' and 'fairy-tale'."

${ }^{12}$ Over the year, some circumstances appear to be more favourable to the enactment of a fairy tale; cf. Ó Giolláin (1991: 201): "On two festivals, Bealtaine or May Day and Samhain or Halloween respectively, the boundary days of the summer and winter halves of the year [---] the barrier between the mortal and supernatural worlds came down and otherworld beings moved freely among women and men." 


\section{REFERENCES}

AT 1961 = Thompson, Stith 1961. The Types of the Folktale: A Classification and Bibliography. Antti Aarne's Verzeichnis der Märchentypen (FF Communications No. 3). Translated and enlarged by Stith Thompson. Helsinki: Academia Scientiarum Fennica.

ATU 2004 = Uther, Hans-Jörg 2004. The Types of International Folktales: A Classification and Bibliography. FF Communications 284-286. Helsinki: Academia Scientiarum Fennica.

Bascom, William 1965. The Forms of Folklore: Prose Narratives. Journal of American Folklore, Vol. 78, No. 307, pp. 3-20. DOI: 10.2307/538099.

Ben-Amos, Dan 2010. Straparola: The Revolution That Was Not. Journal of American Folklore, Vol. 123, No. 490, pp. 426-446. http://dx.doi.org/10.1353/jaf.2010.0000.

Blécourt, Willem de 2012. Belief Narratives and Genre. In: Zoja Karanović \& Willem de Blécourt (eds.) Belief Narrative Genres. Novi Sad: ISFNR, pp. 9-10. Available at http://www.ff.uns.ac.rs/vesti/aktuelno/2011/BNN_zbornik_konacna.pdf, last accessed on June 17, 2016.

Bottigheimer, Ruth B. 2002. Fairy Godfather: Straparola, Venice, and the Fairy Tale Tradition. Philadelphia: University of Pennsylvania Press.

Bottigheimer, Ruth B. 2003. The Ultimate Fairy Tale: Oral Transmission in a Literate World. In: Hilda E. Davidson \& Anna Chaudhri (eds.) A Companion to the Fairy Tale. Cambridge: D.S. Brewer, pp. 57-70.

Bottigheimer, Ruth B. 2009. Fairy Tales: A New History. Albany: State University of New York.

Christiansen, Reidar Th. 1971-1973. Some Notes on the Fairies and the Fairy Faith. Béaloideas, Vols. 39-41, pp. 95-111. http://dx.doi.org/10.2307/20521348.

Dégh, Linda 1972. Folk Narrative. In: Richard M. Dorson (ed.) Folklore and Folklife: An Introduction. Chicago \& London: The University of Chicago Press, pp. 53-84.

Dégh, Linda 1996. What Is A Belief Legend? Folklore, Vol. 107, Nos. 1-2, pp. 33-46. http://dx.doi.org/10.1080/0015587X.1996.9715912.

Folktales and Fairy Tales $2016=$ Folktales and Fairy Tales: Traditions and Texts from around the World. Edited by Anne E. Duggan \& Donald Haase, with Helen Callow. Santa Barbara: Greenwood/ABC-CLIO.

Hartland, Edwin S. 1914. Popular Studies in Mythology, Romance, and Folklore. London: Nutt.

Honti, John Th. 1936. Celtic Studies and European Folk-Tale Research. Béaloideas, Vol. 6, No. 1, pp. 33-39. http://dx.doi.org/10.2307/20521905.

Jason, Heda 1971. Concerning the 'Historical' and the 'Local' Legends and Their Relatives. Journal of American Folklore, Vol. 84, No. 331, pp. 135-144. http://dx.doi. org/10.2307/539740.

Littleton, C. Scott 1965. A Two-Dimensional Scheme for the Classification of Narratives. Journal of American Folklore, Vol. 78, No. 307, pp. 21-27. http://dx.doi. org/10.2307/538100. 
Lüthi, Max 1986 [1982]. The European Folktale: Form and Nature. Trans. by John D. Niles. Bloomington \& Indianapolis: Indiana University Press.

Lysaght, Patricia 1995. Traditional Beliefs and Narratives of a Contemporary Irish Tradition Bearer. In: Mare Kõiva \& Kai Vassilijeva (eds.) Folk Belief Today. Tartu: Institute of Estonian Language \& Estonian Literary Museum, pp. 289-308. Available at http://www.folklore.ee/rl/pubte/ee/usund/fbt/lysaght.pdf, last accessed on June 16, 2016.

Mincu, Marin 1978. I mondi sovrapposti: la modellizzazione spaziale nella fiaba romena. Torino: Giappichelli.

Ní Bhrolcháin, Muireann 2009. Introduction to Early Irish Literature. Dublin: Four Courts.

Ó Giolláin, Diarmuid 1991. The Fairy Belief and Official Religion in Ireland. In: Peter Narváez (ed.) The Good People: New Fairylore Essays. Lexington: The University Press of Kentucky, pp. 199-214.

Propp, Vladimir J. 2003 [1958]. Morphology of the Folktale. Austin: University of Texas Press.

Rolleston, Thomas W. 1911. Myths and Legends of the Celtic Race. New York: Crowell. Available at https://archive.org/details/mythslegendsofc00roll, last accessed on June 16, 2016.

Stewart, Susan 1991. Notes on Distressed Genres. Journal of American Folklore, Vol. 104, No. 411, pp. 5-31. http://dx.doi.org/10.2307/541131.

Swann Jones, Steven 1995. The Fairy Tale: The Magic Mirror of the Imagination. New York: Twayne Publishers.

The Greenwood Encyclopedia of Folktales and Fairy Tales 2008. Vol. 1. Ed. by Donald Haase. Westport \& London: Greenwood Press.

Thompson, Stith 1977 [1946]. The Folktale. Berkeley \& Los Angeles: University of California Press.

Valk, Ülo 2012. Legends as Narratives of Alternative Beliefs. In: Zoja Karanović \& Willem de Blécourt (eds.) Belief Narrative Genres. Novi Sad: ISFNR, pp. 23-29. Available at http://www.ff.uns.ac.rs/vesti/aktuelno/2011/BNN_zbornik_konacna.pdf, last accessed on June 16, 2016.

Vaz da Silva, Francisco 2010. The Invention of Fairy Tales. Journal of American Folklore, Vol. 123, No. 490, pp. 398-425. DOI: 10.5406/jamerfolk.123.490.0398.

Williams, Noel 1991. The Semantics of the Word 'Fairy': Making Meaning Out of Thin Air. In: Peter Narváez (ed.) The Good People: New Fairylore Essays. Lexington: The University Press of Kentucky, pp. 457-475.

Yeats, William B. 2002 [1888]. Irish Fairy Tales. Thirsk: House of Stratus.

Ziolkowski, Jan M. 2010. Straparola and the Fairy Tale: Between Literary and Oral Traditions. Journal of American Folklore, Vol. 123, No. 490, pp. 377-397. http:// dx.doi.org/10.1353/jaf.2010.0002.

Zipes, Jack 2000. Introduction. In: Jack Zipes (ed.) The Oxford Companion to Fairy Tales. New York: Oxford University Press, pp. xv-xxxii. 
Zipes, Jack 2010. Sensationalist Scholarship: A Putative 'New' History of Fairy Tales. Cultural Analysis, Vol. 9, pp. 129-155. Available at http://socrates.berkeley. edu/ caforum/volume9/vol9_eventsdebates1.html, last accessed on June 17, 2016.

Zipes, Jack 2012. The Irresistible Fairy Tale: The Cultural and Social History of a Genre. Princeton: Princeton University Press. 